\title{
Parental Sensitivity and Their Awareness on a Child Sexual Harassment
}

\author{
Abdul Razaq Bin Ahmad ${ }^{1}$, Mohd Mahzan Awang ${ }^{2}$ \& Nawar Fasehah Mohd Ehwan ${ }^{3}$ \\ ${ }^{123}$ Faculty of Education, The National University of Malaysia, MALAYSIA \\ E-mail:nnawar_1815@outlook.com
}

\begin{abstract}
This paper surveyed parental sensitivity and their knowledge towards a child sexual harassment. The assumption is that if parents are sensitive towards a child sexual harassment, they will take preventive actions such as educating their child on sexual prevention education. The study utilized a survey research method using a set of questionnaire that had been developed based on the research carried out by Mohan, et.al (2015) and Mlekwa, et.al. (2016). This study involved 120 parents who has a child at the age of one until 17 years old. The data gathered then analyzed using Statistical Package for Social Sciences (SPSS) version 22.0, involving description statistics. Result shows that the parents' knowledge and attitudes regarding child sexual harassment is high. This means that they are quite knowledgeable towards their child safety.
\end{abstract}

Keywords: Sexual harassment, knowledge, sensitivity, child

\section{Introduction}

Child sexual harassment occurs all over the world. It is a serious social problem that should be taken seriously by all parties as it affects the physical and mental health of the victim. The increase in crime rates has made parents more concerned about ensuring the safety of their children. The questions raised by the parents against the precautionary measures taken by the government to ensure the punishment to the offender are in line with the traumatic effects the family will face, especially the victim himself in his future life. According to NCCAN (1978) in Wurtele (2008), child sexual abuse is defined as the touch or interaction between children and an adult with the child being used as a sexual stimulus to the perpetrator or other person. As a result, the government took steps to amend the Child Act 2001 (AKK
2001 ) in 2016. This effort was carried out at the urging of R.AGE, a group of young journalists, who took the risk of studying in more detail about Child Sexual Grooming in 2016 The 2001 AKK amendment shows that the Malaysian government is increasingly committed to ensuring that child protection and protection is enhanced. The dissemination of information on child sexual abuse is crucial to ensuring that the percentage of crime that minimizes children is minimized. This is in line with Tutty's (1993) statement that, as more parents become aware of child sexual abuse, the more they can identify their children's level of awareness of child sexual abuse prevention education. Briggs (1988), on the other hand, states that only one parent talks with their children about contact with the confidential and reports it to trusted adults. However, these discussions often involve discussions with girls rather than boys (Chen \& Chen, 2005). Furthermore, in a Deblinger study, Thakkar-Kolar, Berry \& 
Shroeder (2010) stated that most parents $(93 \%)$ talked about predators who are strangers to people rather than people they know, such as adults who are known by victims. (64.5\%), parents $(26.3 \%)$ and siblings $(24.6 \%)$. This study is supported by the results of Wurtele, Kvarternick \& Franklin (1992), Briggs (1998), Chen \& Chen (2005) and Chen, Dunne \& Han (2007) where over $95 \%$ of parents discuss the dangers of strangers.

\section{Sexual Harassment: Concerns Revolving Parenthood}

Section 2 of the Children Act 2001 defines children as individuals under the age of 18 and at this age is the age at which parents feel that education is very important in determining the child's future pattern. Therefore, it is not surprising that children under the age of 18 are more likely to explore their surroundings and find answers in every aspect that arouses their curiosity. The attitudes of children in this phase who want to satisfy their curiosity expose them to the dangers that no parent can imagine such as being a victim of paedophilia or child sexual abuse. Therefore, sex education is seen as important for teachers and parents to teach to minors. This is because, children are often misunderstood by the meanings shown by adults towards themselves and this will makes them vulnerable victims (Nur Saadah \& Siti Aishah, 2017).

Issues of child sexual abuse around the world seem to be endless. Study by study was conducted to identify the causes and several strategies were put in place to prevent this from happening. Tan and Yan (2004) stated that mothers were seen as more likely to attend child sexual abuse prevention seminars, which learned about child sexual abuse and believed that child sexual abuse led to physical injury. This shows that fathers are always taking steps to ensure the safety of their children. Simply giving a work reason is a way to avoid attending a seminar or campaign. However, government-run information or campaigns are no longer confined to physical campaigns that are held at certain places and times, in fact, campaigns and information on sexual abuse crimes can now also be run virtually. As such, there is no reason for parents to refrain from paying attention to issues surrounding their children. Only a few parents are taking steps to discuss sex education with their children. The study of Chen, et.al (2007) noted that some parents, of whom only $50 \%-70 \%$ spoke about the sensitive, touching, rejecting and telling of trusted adults. This will make it harder for the government to reduce the rate of child sexual abuse crimes. When parents rarely talk or teach their children about good and bad touch, children are more likely to be confused by the touch that an adult makes on them as they thought that the touch that they are experienced is a touch of love by an adult to them.

Besides that, society considers the role of teaching sex education supposedly to be mother's responsibility. Briggs (1988) stated that, parents who have children between the ages of three and 12 years old considered the role of educating or discussing on childhood sexual abuse was a mother's responsibility. This is because mothers are people who are known for their motherly instincts who always want the best for their child, especially in terms of the safety of their children. However, the role of educating child regarding the sexual harassment should be taken by both parents. Attending seminars or campaigns related to child sexual abuse is one of the steps parents can take to have a better education on information on child sexual abuse issues. However, there are some parents consider their children too young to understand sex education. In the study of Deblinger, et.al (2010), parents provide reasons for not discussing child sexual abuse prevention education: children are too young to understand, and do not know how to just to explain. This parental coercion will disrupt the education of child sexual abuse prevention education.

However, it is quite shocked when some parents point out that teaching sex education to their child is unnecessary considering that child sexual abuse cases are isolated crimes. In Chen's study, et.al (2007) showed that $7.5 \%$ of parents considered child sexual abuse prevention education unnecessary as this problem is rare. Parental perception that child sexual abuse cases are isolated due to child sexual abuse cases not reported by parents, and the media that could be due to shyness, refusal to report or lack of knowledge of protection (BH Online, 2019).

Despite the campaigns being broadcast on many billboards along the road, television, newspapers, and radio, the case is seen as endless as the percentage of crime cases is increasing. Statistics show that 22,234 cases of child sexual abuse were recorded from 2010 to May 2017, with an average of 3,176 cases per year (Royal Malaysian Police, 2017). The total represents four categories of sexual abuse that registered a total of 13,272 cases of rape, followed by 6,014 cases of rape, 1,796 cases of misconduct and 1,152 cases of illegal sex offenses. This makes parents take precautions to ensure the safety of their children. However, can the safety of their children be respected in the wake of pedophilia cases that are increasingly gaining public attention today?

Parental education is very important in ensuring that children know the boundaries of their relationships even with their close relatives (Shahrom Abu, 2019). The study also showed that one in four girls and one in six boys had been 
victims of sexual abuse before the age of 18 (Astro Awani, 2019). This situation is particularly alarming when a study by the Public Health Institute in 2018 conducted on students at 212 schools recorded $31.9 \%$ of students had sexual experience before the age of 14 . And of those, on average, $10 \%$ to $40 \%$ of unmarried girls in the age group between 13 and 19 years of age have unwanted pregnancies.

\section{Research Purpose and Objectives}

This study aimed to identify the sensitivity and awareness of parents towards their children for sexual harassment. Specifically, this study identifies the levels of parental knowledge of child sexual abuse, and their preventive actions of child sexual harassment.

\section{Methodology}

This study used a quantitative survey research method design. It utilized a random sampling method with 120 parents involving children under the age of 18 and below. The instruments used in this study were the 2-point Likert scale questionnaire for measuring parental knowledge and the 5-point Likert scale to examining their preventive actions. The study consisted of 31 items divided into four main constructs, namely 1 item for demographics, parental knowledge of child sexual abuse issues (10 items), parental attitudes toward child sexual abuse issues (10 items) and practices parents to children (10 items). The instruments in this study were developed from the questionnaire used in the study of Mohan, Kochuthresiamma \& Joice (2015) and instrument by Mlekwa et. al (2016).

\section{Findings and Discussion}

The study involved 120 parents that own children under the age of 17 and gender composition records 60 mothers and 60 fathers.

Table 1. Parents' knowledge level

\begin{tabular}{lcc}
\hline Items & $\begin{array}{c}\text { True } \\
\text { N (\%) }\end{array}$ & $\begin{array}{c}\text { False } \\
\mathbf{N}(\%)\end{array}$ \\
\hline $\begin{array}{l}\text { Child sexual harassment occurs around } \\
\text { of the world. }\end{array}$ & $\begin{array}{l}(95.0 \\
\%)\end{array}$ & 6 \\
& $15 \%)$ \\
Children has high risk to be abused by & 114 & \\
someone they know. & $(95.0$ & 6 \\
The doer of the child sexual harassment & 112 & $(5 \%)$ \\
has high possibilities to repeated the & $(93.3$ & 8 \\
crime. & $\%)$ & $(6.7 \%)$ \\
Child sexual harassment always happen & 114 & 6 \\
to the adolescent. & $(95 \%)$ & $(5 \%)$ \\
There is no clear sign or proof when a & 113 & 7
\end{tabular}

child is sexually abused.

Woman normally will not do sexual harassment on children.

Boys normally will not be targeted to be sexually abused.

$\begin{array}{cc}(94.2 \%) & (5.8 \%) \\ 114 & 6 \\ (95 \%) & 5 \%) \\ 101 & 19 \\ (84.2 \%) & (15.8 \%)\end{array}$

The doers normally will spent an expensive gift or an amount of money on child without clear reasons.

$119 \quad 1$

$(99.2 \%) \quad(0.8 \%)$

Child who had been sexually abused will detained by the doer from exposing the sexual harassment.

In most cases, the doer of the child sexual abused is man.

$\begin{array}{cc}120 & 0 \\ (100 \%) & (0 \%) \\ 120 & 0 \\ 100 \%) & (0 \%) \\ \begin{array}{c}\mathbf{9 5 . 0 8} \\ \%\end{array} & \mathbf{4 . 9 2 \%}\end{array}$

According to Table 1, all (100\%) parents know that children who are victims of sexual abuse will be prevented from reporting to the person they believe the acts of the predator against the victim and that the perpetrator of the crime is male. Almost all $(99.2 \%)$ parents knew of predatory tactics to get victims' attention by buying them expensive gifts or money for no apparent reason. In addition, a total of 114 (95\%) parents acknowledged that child sexual abuse crimes occur worldwide, and that perpetrators of these crimes are the most well-known victims, as well as predators looking for victims in their teenage years and believe that women will not commit sexual abuse of children. $94.2 \%$ of parents believed that there would be no clear evidence of a victim's physical condition if they were the victim of child sexual abuse and that the predator would repeat the same offense against the victim $(93.3 \%)$. However, the number of parents who believe that boys are not the target of predators is $84.2 \%$

Table 2. Levels of Parental Prevention of Child Sexual Abuse

\begin{tabular}{|c|c|c|c|c|c|}
\hline Item & $\begin{array}{l}\text { Never } \\
\text { n }(\%)\end{array}$ & $\begin{array}{c}\text { Rarel } \\
\mathbf{y} \\
\mathbf{n}(\%)\end{array}$ & $\begin{array}{c}\text { Sometim } \\
\text { es } \\
\text { n }(\%)\end{array}$ & $\begin{array}{l}\text { Often } \\
\text { n }(\%)\end{array}$ & $\begin{array}{c}\text { Alway } \\
\text { s } \\
\text { n }(\%)\end{array}$ \\
\hline $\begin{array}{l}\text { I told my } \\
\text { kids to not } \\
\text { follow } \\
\text { strangers. }\end{array}$ & $\begin{array}{l}3 \\
(2.5 \% \\
)\end{array}$ & $\begin{array}{l}3 \\
(2.5 \% \\
)\end{array}$ & $\begin{array}{c}3 \\
(2.5 \%)\end{array}$ & $\begin{array}{l}15 \\
(12.5 \\
\%)\end{array}$ & $\begin{array}{c}96 \\
(80 \%)\end{array}$ \\
\hline $\begin{array}{l}\text { I told my } \\
\text { kids to not } \\
\text { accept any } \\
\text { gift from }\end{array}$ & 0 & $\begin{array}{l}3 \\
(2.5 \% \\
)\end{array}$ & $\begin{array}{c}3 \\
(2.5 \%)\end{array}$ & $\begin{array}{l}80 \\
(66.6 \\
\%)\end{array}$ & $\begin{array}{l}34 \\
(28.3 \\
\%)\end{array}$ \\
\hline
\end{tabular}


I told my

kids to not

follow

strangers

eventhoug

$\mathrm{h}$ the

stranger

were

asked for

direction.

I told my

kids

regarding

the bad

touch on

the private

part.

I told my

kids

regarding

the private

part of

their

body.

I teach my

kids to say

"NO"

when

someone

ask to see

their

private

part.

I told my

kids to

report to

me if

someone

try to

touch

their

private

part.

I teach my

kids about

their

safety by

doing

some

action for

them to

have clear

vision on

the

situation.

I told my

kids to
3
$(2.5 \%$

)

3
$(2.5 \%)$

80

(66.6

$\%)$

34

(28.3

$\%)$

\section{7}

(64.2

$\%)$

17

(14.2

$\%)$

71

(59.2

$\%)$

46

(38.3

$\%)$

38

(31.6

$\%)$

74

(61.6

$\%)$

80

(66.6

$\begin{array}{cc}(2.5 \%) & (66.6 \\ & \end{array}$

34

(28)

report

)

$\%)$

their

everyday

activity to

me.

I told my

kids

regarding

the

support

system

hotline

number.

Total

$\begin{array}{ll}1 & 2 \\ (0.8 \% & (1.6 \%\end{array}$

4
$(3.3 \%)$

69

$\%)$

(36.6

$\%$ )

Result shows that $80 \%$ of parents teach their children not to go after others, even if the individual is known by their child, except with the consent of their parents. This finding is in line with the findings of Chen \& Chen (2005) who reported that $95.3 \%$ of parents discussed with their child for parental consent before following someone even if the individual was known to the victim. $66.6 \%$ of parents have also discussed with their child not to go with an individual to ask for directions or nearby stores, as well as refusing to accept gifts from strangers and reporting to parents if a safety rule is violated by someone. $65 \%$ of parents provide audio visual aids for the prevention of child sexual abuse to keep children clear of the rules being discussed. $74(61.6 \%)$ and $31.6 \%$ parents frequently and repeatedly taught their children to say "NO" in the event of individuals wanting to touch or see their privacy. The results of this study are in line with the Deblinger, Thakkar-Kolar, Berry \& Shroeder (2010) study where $93 \%$ of children were taught to tell their parents what was happening outside the home and $74.1 \%$ were taught to say no to strangers. However, this finding is not in line with Chen \& Chen's (2005) study which found that only less than $50 \%$ of parents talk to their children about touch, reject, and tell trusted adults. The practice of prevention of sexual abuse is very important to children starting at a young age so that they can be regular in their day-to-day life and respect the boundaries of the practice as suggested by Dr. Faridah, Director of Family Health Development Division, Ministry of Health, in an interview with Astro Awani dated April 23, 2019, said that parental education is very important in ensuring that children know the boundaries of their relationships even with their close relatives (Shahrom Abu, 2019).

\section{Conclussion \& Recommendation}

Parents' knowledge of the issue of child sexual abuse is very important in preventing child sexual abuse crimes. Based on the findings of the above study, it is very important to 
educate parents on child sexual abuse in terms of the types, factors, effects and symptoms that lead to child sexual abuse. The focus on disseminating information on child sexual abuse should be emphasized by utilizing all types of mass media such as print and electronic media. Government and non-government bodies need to intensify efforts by launching a campaign to raise parental awareness of child sexual abuse by targeting parents of all ages and socioeconomic backgrounds.

\section{Acknowledgemet}

This research has been funded by The National University of Malaysia (UKM) GG-2018-013.

\section{References}

[1] Chen, J. Q. \& Chen, D. G. (2005). Awareness of Child Sexual Abuse Prevention Education among Parents of Grade 3 Elementary School Pupils in Fuxin City, China. Health Education Research, 20(5), 540-547.

[2] Chen, J. Q., Dunne, M. P., \& Han, P. (2007). Preventionof Child Sexual Abuse in China: Knowledge, Attitudes, and Communication Practices of Parents of Elementary School Children. Child Abuse \& Neglect, 31(7), 747-755

[3] Deblinger, E., Thakkar-Kolar, R. R., Berry, E. J., \& Schroeder, C. M. (2010). Caregivers' Efforts to Educate Their Children about Child Sexual Abuse: A Replication Study. Child Maltreatment, 15(1), 91-100.

[4] Fatmeh Ahmad Alzoubi, et.al (2018). Mothers' Knowledge \& Perception about Child Sexual Abuse in Jordan. Child Abuse \& Neglect 75, 149-158.

[5] Hunt, D.P. (2003). The Concept of Knowledge and How to Measure It. Journal of Intellectual Capital, 4 (1), 100118.

[6] Marzieh Navaei, et.al. (2018). Effect of Group Counselling on Parents' Self-Efficacy, Knowledge, Attitudes and Communication Practice in Preventing Sexual Abuse of Children Aged 2-6 Years: A Randomized Controlled Clinical Trial. IJCBNM 2018, 6 (4), 285-295.

[7] Mlekwa, F.M., et.al (2016). Knowledge, Attitudes and Practices of Parents on Child Sexual Abuse and Its Prevention in Shinyanga District, Tanzania. Tanzania Journal of Health Research, 18 (4).

[8] Mohammad Hassan Sahebihagh, et.al. (2016). Knowledge, Attitude and Practice of Community Health Workers Regarding Child Abuse in Tabriz Health Centers in 2015 - 2016. IJCBNM 2017, 5 (3), 264-274.

[9] Mohammad Hassan Sahebihagh, et.al. (2016). Knowledge, Attitude, and Practice of Teachers in Tabriz (Iran) Elementary School Regarding Child Abuse (2015-
2016). International Journal of Medical Reseacrh \& Health Sciences 2016, 5 (9), 336 - 343.

[10] Monica Ruiz-Casares (2011). Child Protection Knowledge, Attitudes and Practices in Central and Western Liberia. Mcgill University \& CSSS De La Montagne.

[11] Muzdalifat Abeid, et.al. (2015). Knowledge and Attitude towards Rape and Child Sexual Abuse: A Community- Based Cross-Sectional Study in Rural Tanzania. BMC Public Health 2015, 15(428).

[12] Nor Shafrin Ahmad (2012). Penderaan Seksual: Keperluan Kriteria Pegawai, Punca Penderaan dan Kes Tidak Dilaporkan. Sosiohumanika, 5(1), 81 - 92.

[13] Robyn, H. \& Walah, K. (2011). Parents' View about Child Sexual Abuse Prevention Education: Systematic Review. Australasian Journal of Early Childhood, 36 (2), 63-76.

[14] Wurtele, S.K. (2008). Behavioral Approaches to Educating Young Children and Their Parents about Child Sexual Abuse Prevention. JOBA-OVTP, 1(1), 52-64.

[15] Voas, D. (2014). Towards a Sociology of Attitudes. Sociological Research Online, 19 (1).

[16] Zanariah Noor (1985). Penderaan Kanak-Kanak oleh Ibu Bapa atau Penjaga dan Implikasinya Mengikut Undang-Undang Sivil dan Undang-Undang Keluarga Islam di Malaysia. Jurnal Perspektif, 7 (2), 66 - 80. 